\title{
A Case for Caution: Eighteen Years of Bologna and Ramifications for the United Sates
}

\author{
Zachary Mngo* \\ Department of Humanities \& Social Sciences, Prince Mohammad Bin Fahd University, SaudiArabia
}

Submission: July 30, 2018; Published: November 08, 2018

*Corresponding author: Zachary Mngo, Department of Humanities \& Social Sciences, Prince Mohammad Bin Fahd University, P.O. 1664\r\nAl Khobar 31952\r\n, Saudi Arabia

\begin{abstract}
The spread and influence of older European higher education models and the current Bologna Process (BP) have been mostly linked to its colonial and neocolonial hegemony. However, the 1999 convergence of European models under the umbrella of the BP reform has had implications beyond the colonial and neocolonial spheres, with its effects impacting even the well-established and reputable education systems of North America. Unlike the countries of Africa, Latin America and the Caribbean, and the Asia Pacific, the United States of America did not have any reasons to embrace the BP models. However, they are still indirectly affected by it.

The international nature of academe characterized by cooperation and exchanges, has made it impossible for United States tertiary education systems to avoid the effects of the European BP reform entirely. Student and faculty mobility, transferability of degrees, and joint and dual degree offerings have grown significantly as a result of the "external dimension" objectives of the Bologna reform. Considering that we live in a highly globalized higher education market, which is characterized by partnerships, exchanges, including competition between European and the United States colleges and universities over international students, the BP ultimately has and will continue to influence the calculations of higher education stakeholders in the United States. Keywords: Bologna Process, (BP) education reform, student mobility, joint-programs, exchange.
\end{abstract}

Keywords: Bologna; Netherlands; Statistics

\section{Introduction}

The European Bologna Process is the most historic higher education reform of the 20th with wide ranging global ambitions and implications. It has been described as a unique model of systemic integration that "has not been achieved anywhere else, even in some federal nations such as the United States where higher education remains highly state or province bound"[1].

Zgaga [2] reports that the goal of the "external dimension" of the Bologna Process is not only to make the European Higher Education Area [3] attractive enough to the rest of the world in order to draw in more of the best foreign students and scholars, but also to boost the quality of higher education within Europe itself, as a way of making universities more effective. The report points out that such an appeal is important within the presentday knowledge-based economy, which the world's richest nations regard as the sine qua non of economic growth. The 2009 Prague Report confirmed this view but also clearly stated that the main goal of the Bologna Declaration was to ensure that the European higher education system acquires a worldwide degree of attraction. This report confirms that one of the primary goals of the reform has always been to render European higher education competitive in higher education marketing, dominated by United States and the United Kingdom.
Labi argues that, since the inception of the Bologna Process, Britain is no longer theUnited States' only competitor for international students in Europe because ContinentalEuropean countries such as the Netherlands, France, Belgium, Germany, and Finland are increasingly becoming popular destinations for international students. In order to attract foreign students, European universities and governments have adopted aggressive online marketingstrategies, created foreign recruitment offices, and favored not only the use of English in classrooms but also the creation of English programs. The UNESCO Institute for Statistics $[4,5]$ indicates significant increases in the enrollment of foreign students in four European countries from 1999 to 2005: Britain $(232,540$ to 318,399$)$, Germany $(178,195$ to 259,797$)$, France (130,952 to 236,518$)$, and Finland $(4,847$ to 8,442$)$.Since the BP reform, cooperation between both governments and colleges and universities has grown tremendously, influencing governance, funding, student and faculty mobility, and curricula [6,7].

Altbach [8-11] argues in favor of international cooperation among tertiary education institutions by asserting that no institution of higher education can survive on its own and stay viable in the 21st century. Altbach [8] affirms that internationalization is a natural and not so new phenomenon because, historically, academe has always been international in scope, even when most 
of the time it has been characterized by inequalities. Limited access to modern technology and inadequate infrastructure caused by insufficient funding has greatly weakened the ability of universities in developing countries to effectively compete internationally. Notwithstanding this, international activities of universities have dramatically expanded in volume, scope, and complexity during the past two decades [10].

Many worldwide higher education reforms, especially the BP, have enabled universities to enter a new "virtual" or "e-learning" market, and to intensify cooperation and exchange through joint programs and exchange programs. This has led to a new kind of higher educational institutional management, strategic leadership, and organizational structures [12]. Yang points out that higher education reform has played a major role in developing the new quality of educational leadership that is so vital to the modernizationprocess. It is against this background of perceptions regarding higher education trends that the European Bologna reform went beyond encouraging the convergence of European systems to establishing the goal of promoting the model worldwide through partnerships[13].

Adelman [14]affirms that parts of the Bologna Process have already been imitated in Latin America, North Africa, and Australia. According to Adelman[14] the core features of the Bologna Process have enough momentum to become the dominant global higher education model within the next two decades. While recognizing the fact that United States' initial reaction to the Bologna Process had been almost dismissive, he points to the fact that since 2008 things have begun to change. Recent higher education conferences in the U.S. have "panels, presentations, and intense discussions of Bologna approaches to accountability, access, quality assurance, credits and transfer, and, most notably, learning outcomes in the context of the disciplines" [14].

In neighboring Canada, initial reaction to the Bologna Process was positive, and demonstrated a desire by higher education authorities to understand it better. The conclusions of the 2009 AUUC report recognize that the Bologna Process is not without controversy and does not provide the single answer to all challenges to higher education. However, it also emphasizes the need for collaboration between Canadian and European universities, and acknowledges the potential of the Bologna Process "as a trust-building exercise through developing transparency in higher education systems and procedures, and fulfilling the responsibility for enabling students to develop the knowledge, skills, and aptitudes to survive in the labour market and participate in their societies" (AUUC, 2009, p. 13). The Conference on Canadian Perspectives on the Bologna Process, held in March 19-20, 2009 at the University of Alberta, Edmonton, gives a largelypositive appraisal. It points out in one of its conclusions that the Bologna Process is an expression of the increasing need for a global understanding of higher education (AUUC, 2009).

Despite the improving trends in favor of students' mobility, exchange programs, and international students' enrollment in the universities of mainland Europe, the U.S. continues to outpace Europe in the enrollment of international students. Data from the National Center forEducation Statistics (NCES) (2017) indicate a rise of international students' enrollment from14,791,000 in 1999 to $20,185,000$ in 2017 , a $26.72 \%$ increase. Notwithstanding, Europe has gained some grounds in the competition for international students with the United States since the European Bologna Process reform. By spreading the BP models and intensifying cooperation with universities in Asia, Latin America, and Africa, continental Europe has become more and more attractive-with an increasing number of students from these regions choosing Europe over America. Asia-Pacific countries, notably Australia and New Zealand that have also adopted BP models have also become more attractive to students from Asian countries who constitute the largest block of international students studying in the United States $[4,5]$.

\section{Purpose}

The goals of the Bologna Process were not limited to ensuring a converging of European higher education systems. A further objective was to increase the competitiveness of the European models by aiding in their spread outside Europe. This goal was expressed clearly by the 1999 Bologna Process Accords. The May 1998 Sorbonne Declaration leading to the BolognaAccords emphasized: "the international recognition and attractive potential" of European models.The Bologna Accords emphasized the "the objective of increasing the international competitiveness of the European systems of higher education" and claimed to ensure "a world-wide degree of attraction" [2]. One of the undeclared but obvious objectives of the BP was to strengthen European higher education institutions in order to be able to compete effectively against the domination of American colleges and universities. This objective came to the fore in 2003 when the French Education Minister, Luc Ferry, told French universities to adopt an alternative to the "American globalization" by constructing a European model of higher education that would attract more foreign students and strengthen their public-service ethos. He argued that it is the only sure growth path for European higher education since there are neither the resources nor the desire to prohibit the private U.S. universities already establishing themselves in European countries [15].

This study focuses on the implications of the BP reform for American higher education in areas such as international students' enrollment, faculty mobility, study abroad, transferability of degrees, and joint and dual degree offerings, while pinpointing a noticeably gradually tightening competition for international students between U.S. and EU colleges and universities.

\section{Research Question}

What are the implications of the European Bologna Process reform for the United States of America regarding international student enrollments, faculty and student mobility, study abroad, transferability of degrees, and joint and dual degree offerings? 


\section{Bologna Process Gains Since 1999}

The European Bologna Process remains the largest and most successful worldwide higher education harmonization initiative. The intergovernmental, inter-institutional process to harmonize degree structures, qualifications frameworks and quality standards across Europe that began 18 years ago, initially involving 29 European signatory countries, is now encompasses 47-member countries [16]. The movement has made considerable historical advancestoward convergence in many areas. Significant gains are noticeable, especially regarding the internationalization or external dimension objective of the reform as well as with the goals of the EHEA, a centerpiece of the BP reform. Great strides have been made to align the EHEA degree structures and promote academic mobility across the continent of Europe. These successes have placed the reform in an exceptional position as an example for other regions of the world interested in establishing similar crossborder agreements in higher education [17].The initially stated goals of the BP included easing readability and comparability of degrees, establishing a common European credit transfer system (ECTS), adopting the two-cycle system (undergraduate/ graduate), cooperation in quality assurance, and promoting both mobility and the attractiveness of the EHEA. As of today, the implementation of the ECTS as a transfer and accumulation system is almost complete. Comprehensive internationalization and mobility strategies, which were not in the EHEA at its creation, are now being developed and applied by many EU countries. According to the European Commission (2013), the European higher education strategy is encouraging EU member states to implement comprehensive internationalization and mobility strategies likely to impact EU and non-EU countries[18-20].

Apart from these more recent concerted efforts, the rapid growth in the number of English-language programs at European universities has helped to facilitate student mobility, which is one of the primary objectives of the Bologna Process. The development of dual-degree programs is an essential new trend in Europe's long-term commitment to international highereducation collaboration [5]. According to the January 2009 survey report by the Institute of International Education and the Free University of Berlin, European universities have greatly outpaced American universities in offering international joint-degree and dual-degreeprograms. These programs flourish more in European universities than American universities because the tuitionpaying American students and their universities are more likely to bear the costs of such programs than their European counterparts who tap into a broader range of support from governments and nonprofit groups. As a result, fewer students in American higher education establishments can afford the cost of international joint-degree programs.

The report also points to the weakness of the American studyabroad programs which tend not to integrate students effectively into overseas host institutions because they usually last less than a full semester or academic year and face greater difficulty in obtaining institutional support and recruiting students for such programs.The 2015 European Commission Report summarizes the achievements of the Bologna Process while indicating what remains to be achieved. The report underscored the fact that numerous stakeholders and more than 4000 educational institutions from 47-member countries"have continued to adapt their higher education systems, making them more compatible, modernizing degree structures and strengthening their quality assurance mechanisms" [20]. According to the report, the Bologna Process provided a framework for dialogue and cooperation, which has spread outside Europe. The achievements of the reform go beyond assuring dialogue and collaboration regarding the technicalities of the credit transfer systems, faculty and student mobility, and quality assurance, and now extend to the promotion of European interests, values, and institutions.

Despite the mostly positive progress report on the BP, implementation is moving in different directions and at a widely varying pace, thereby creating some instability in the EHEA. Remarkably, the 2015 European Commission report points to that fact that students and graduates in many countries still face obstacles in having their studies abroad recognized forwork or further study. Worst of all is the conclusion that "graduates too often discover that they do not have the skills and competencies they need for their future careers" (p. 3). These identified weaknesses are an indication that much remains to be done for European higher education to be competitive in a tertiary education market dominated by United States institutions.

\section{BP Implications for United Sates of America}

Even though exporting the European model to the United States was not a direct objective of the external dimension of the Bologna Process, the reform naturally has repercussions for the enrollment of foreign students in American institutions, as well as the exchange of students and faculty between European and American colleges and universities. The drive by European universities to recruit foreign students intensified following the launching of the Bologna Process in 1999[21]. American dominance in the enrollment of foreign students seemed threatened by Europe more than ever before[22,23]. Since the adoption of the Bologna model, which is more compatible with the Anglo-American models, Continental Europe has attracted more students from Asia, Latin America and Africa [16]. In the past, apart from America, Britain has been the preferred European destination for students from Korea, China, India, Pakistan, Philippines, and much of Asia.

Research arguably points to the conclusion that the shifting interest in favor of European higher education is due to the BP reform and its embrace of English programs in many universities in continental Europe. Labi [4] indicates that the strong shift toward English is the most significant attraction of foreign students to Western Europe. She adds that as early as the 1950s the Netherlands became the first non-Anglophone country in Europe to teach courses in English, and today offers 1,300 programs in the language. The trend has intensified withGermany offering more 
than 500 degrees in English and one quarter of university courses in Denmark are offered in English. Finland, with a population of about 5 million people, offers 400 English-language graduate programs. Labi [4] underscores the significance of the trend toward the embrace of English language programs in European universities by pointing to the fact that "even France, with its deep-seated scorn for the creeping Anglicization of its national language, assures foreign students in its marketing brochures that they "no longer need to be fluent in French to study in France" (p. A29).

The external component of the Bologna Process has encouraged and enabled European countries to extend collaboration in the areas of research, student and faculty mobility and exchange [2]. Several European universities are developing exchange programs with African and Asian universities. These targeted outreaches explain why Europe has become very competitive in attracting Asian students who have customarily been the largest block of foreign students in the Unites States. In 2003 they comprised more than half (51\%) of foreign students in the United States [24]. Today, China and India together account for more than 47 percent of all current foreign students in the U.S., and mobility trends in these two countries are of vital consequence for many U.S. universities. However, draconian immigration policies currently supported by the U.S. are beginning to have an effect. Trines $[25,26]$ points to a sudden decrease in the visas issued to students from the Asian continent (including the Middle East). If past trends are an indication as to what could happen in the future, the likelihood is that students from these regions will find viable alternatives not only in Australia and the UK but also in continental Europe, which continues to create more international student-friendly programs in the Englishlanguage-English representing the representing the closest approximation to a twenty-first century lingua franca.

\section{Understanding the Inevitability of Cooperation in Higher Education}

The creation of the BP reform was a move in line with a global trend in the 1990s aimed at recognizing the importance of internationalization and fostering it around the world. Courts [27] states that one of the most traditional and efficient methods for training students to be competent, confident, and comfortable internationally is through exchange programs-jointdegree programs and study-abroad programs. Among the early Americans pursuing this goal are those who studied in European universities in the second half of the 19th century. Study-abroad supporters also argue that through living abroad one could better understand his own country, develop linguistic skills, and gain useful knowledge and skills for fruitful careers in government, business, and education [27-29].

The most reliable component of internationalization in the United States is the international student's component, which has a significant impact on the economy [30]. In the mid-1990s the United States was already considered to be the leading exporter of higher education services. In 1995/1996 the United States ranked first in the number of international students (453,787 students) followed by France $(170,574$ students), Germany $(146,126)$, and the UK $(128,550)$ (WTO Council for Trade in Services, 1998) [31,32]. In the early 1990s, for the first time, more Europeans were studying in the United States than Americans studying in Europe. Even though today the United States remains the leading exporter of education services, it now faces increasing competition from European and Asia-Pacific countries such as Australia and New Zealand, particularly for Asian students, who remain the largest group of international students in the United States [33].

Since the November 2016 presidential elections, the U.S. higher education community has monitored the extent to which the policies implemented during the Trump presidency are affecting the flow of international students to the United States. Recent SEVIS data points to declining enrolment from key countries due to new visa restrictions [26]. Considering that the BP reform improved the interpretation and transferability of European degrees, it is very likely that European universities will become the second choice for international students who are blocked by visa restrictions from attending United States universities. It is imperative for American higher education stakeholders to understand that because of global higher education reforms inspired by the Bologna Process, international students now have attractive alternatives in Europe and Asia-Pacific.

It was with the desire to be competitive and the need to promote European cooperation in the areas of quality assurance, mobility of faculty and students, easy readability and comparability of degrees, that 29 European ministers of education signed the Bologna Accords in 1999. The accords were aimed at promoting a European dimension in higher education that would culminate with the creation of a European Higher Education Area (EHEA) by 2010 [33]. This reform was timely considering that the demand for higher education has increased tremendously in recent years. Even though the trend is worldwide, the rate of increase in demand and accompanying challenges vary from country to country. Teferra and Altbach [11] affirm that a rise in demand for postsecondary education has led to pressures of expansion and "massification" that have added large numbers of students to most African academic institutions and systems. These expansions have encouraged student and faculty exchange programs and expanded campus environments [34]. More competition has developed in recent years as institutions, countries, and regions areintroducing reform that will give them a competitive advantage over others in the struggle to acquire more resources, faculty, the best students, and funding. The BP seemed to have increased the competition significantly for Europe, and dismissiveness on the part of America would be erroneous.

Initiatives by the European Commission to fund cooperation initiatives between European universities and Universities in Africa, Latin America, and Asia is indicative not just of Europe's desire to render its higher education systems attractive; it also demonstrates its appreciation that globalization, from 
the perspective of higher education, raises a certain number of challenges. These challenges and concerns have to do with decisions on curricula, funds to support exchange programs, and cooperation with foreign universities. Forest (2004) states that the way globalization is affecting higher education in developing countries is of interest because these countries will experience the bulk of higher education expansion in future decades. From a policy perspective, globalization impacts upon public policy most prominently in four critical dimensions of higher education: access, funding, internationalization of teaching and research, and quality assurance [35]. American higher education needs to show the same kind of understanding and engagement to maintain its leading position during the first half of the 21st century.

The architects of the BP reform understood that the internationalization of higher education is a necessity. The April 2009 report of the U.S. Government Accountability Office appears to agree with this position. The report stated that Western governments use higher education to advance diplomatic, economic, and other objectives, and employ multiple approaches to attract international students. Reimers [36] asserts that students need "global competency"-the knowledge and skills that help them across disciplinary domains tocomprehend global events and respond to them effectively. He identifies three interdependent dimensions of global competency. The first is that students who have an international higher education experience are more likely to develop a positive approach toward cultural differences and show empathy with people who have other cultural identities.

The students are likely to have an interest and understanding of various civilizations and their histories as well as the ability to see those differences as opportunities for constructive, respectful, and peaceful transactions. The second dimension of global competency is the ability to speak, understand, and think in one or more foreign languages. Finally, students with an international education experience have a broader knowledge of world history and geography, and the global aspects of health care, climate change, economics, politics, international relations, and other issues. Brennan, Locke, and Naidoo [31] argue that successful research has always had an international element, which favors the internationalization of higher education since higher educational institutions serve as large research centers. The interest shown by higher education institutions and governments in the introduction of new exchange programs, the creation of extension campuses, promotion of joint-degree programs, and recruitment of more foreign students is an indication that there is a higher recognition than before of the advantages derived from internationalization. Against this background, cooperation between European and North American higher educational institutions is bound to grow over time. Such partnerships can only be successful if educational organizations on both sides of the Atlantic appreciate and understand the systems they partner with-hence the need for American colleges and universities to fully comprehend the nature and the applications of the various BP models and components across Europe and beyond Europe.

\section{Understanding Bologna Model Qualifications inside Europe}

Despite the almost unanimous adoption of the BP, significant differences still exist in qualification from graduates of various European colleges and universities. These differences vary, at a smaller scale among institutions in the same country but also at a more significant level among countries that have officially joined the reform, depending largely on the pace of adoption and/ or adaptation of the BP models [20]. The European commission Reports (2012/2015) indicate that a third of countries belonging to the EHEA have implemented the Bologna framework. It adds that in another third of EHEA countries, $89 \%$ of students are enrolled while "in the remaining countries, with the exception of Switzerland (63.2\%), Germany (61.9\%), Austria (61.5\%) and Spain (47.9\%) more than $70 \%$ of students are enrolled in threecycle programmes" (p. 49).

It is very important for American educational stakeholders to understand that the $\mathrm{BP}$ is a working progress towards convergence just as is the entire European Project. In like manner with the rest of the European Project, the BP higher education reform is happening amidst significant differences between European national education systems but still ensuring a gradual progress towards a convergent higher education system-significant differences still exist in interpretations, and level and pace of implementation and adaptations of the BP all over Europe. American educational institutions and leaders stand a better chance of correctly interpreting the implications of the BP for partnerships and the enrollment of students from EU and non-EU countries implementing the Bologna reform by trying to understand the overall purpose of the reform which falls somewhat in line with the goals and trend of the European project.

The original goal of the BP process was realistic in the sense that it recognized the need to create a common and not an identical EHEA that would facilitate the comparability of degrees and the mobility of students and faculty within Europe (Armstrong, 2009). The reform provided a set of reference points that enable one European institution to evaluate clearly the educational attainments of a student from another institution. While recognizing the fact that national and institutional variations in curriculum, instruction, programs, and degrees, resulting from historical, political, and socio-cultural influences, are bound to exist, it created a common European credit transfer system (ECTS) degree structure, credit, and quality control structures. This kind of understanding will limit the tendency to generalize when initiating student and faculty exchange programs with European universities or the interpretation of transcripts from Europe. The 2012 BP implementation report on the EHEA indicated that the context for higher education reform and development differs substantially between countries caused by different 
structural realities, including institutional types and demographic challenges. It underscored that despite on establishing National Qualification Frameworks and using the Bologna comparability tools such as the ECTS and the Diploma Supplement, problems persisted in way the tools were understood and implemented. As a result, problems of recognition of qualification and credits in Europe still exist in spite near uniformity in the reforms of threecycle degree structures (BA, MA, PhD).

Moreover, itwould be importantfor educational establishments in the US to know even the minor but significant differences in the implementation of Bologna structures and instruments from one European higher educational institution to another and from one country to country. These considerations can provide much needed guidance and clarity regardingadmission requirements for students from various European universities and the nature of partnerships to pursue.According to Terry (2007) the Council of Graduate Schools (CGS), which representsUnited States institutions who award 95\% of doctorate degrees and $85 \%$ of master's degrees, reported that the Bologna Process is a concern for graduate school deans. He noted thatin summarizing events at the March 2005 conference on "Graduate Education and American Competitiveness," CGS reported that "virtually every speaker at the conference, in one way or another, stated that international competition in graduate education threatens American worldwide leadership in research and innovation and therefore threatens American prosperity." (p. 241)

Terry [37] also points to a presentation by Sybille Reichert, one of the speakers at this conference, who offered a European perspective on the Bologna Process and international competition. She explained that European higher education was undergoing a massive transformation, providing more competition for the United States. Reichert and Tauch [38] pointed to ways in which European graduate education already had surpassed United States graduate education, including the number of Ph.D. graduates, the number of peer-reviewed publications, and significant rankings in a list of the top 200 research institutions. Douglass and Edelstein [22] affirm that there are already signs that the world market for student talent is shifting to the benefit of the United States' competitors; adding that in bad economic times of today, the shift may continue to accelerate.

\section{Understanding Bologna Model Qualifications Worldwide}

It is not enough for admissions officers in American colleges and universities to understand differences in Bologna model ECTS transcripts and non-Bologna transcripts from European graduates seeking admission in American graduate schools. In order to ensure a more reliable interpretation of degrees and transcripts from students seeking graduate admission fromnonEuropean countries that have adopted the Bologna model, it is equally important for graduate admissions officials in the US to understand the differences in various Bologna hybrids outside of Europe. Various BP hybrids are adopted with varying degrees of modifications by tertiary educational institutions in several countries and regions of the world. Just like there is no complete convergence yet in the Bologna Process structures and processes throughout Europe, there is none yet in regional higher education consortiums fashioned after the European model. These groupings include the 2002 LMD (Licence, Mastère, Doctorat) reform in the Maghreb Countries, Latin American and the Caribbean Higher Education Area (ENLACES-IESALC), the CEMAC Higher Education Professional Training and Research Area (CHEPTRA) composed of countries of Central Africa, and the Regional Centre for Higher Education and Development (RIHED) Framework for Regional Integration in Higher Education in Southeast Asia. (Morocco, Algeria and Tunisia).

Eta $[39,40]$ investigates what she named the adoption and adaptation of the Bologna Process reform in the countries of Africa, focusing on Cameroon. Anglophone universities, she points out, did not have to do much adoption and adaptation because they already had the credit system and the two-tier degree structure (BA, MA, and Ph.D.) implemented by Bologna. However, Frenchinspired universities had to not only adopt the credit system but also modified it to accommodate the module and average systems that were previously in place. This example testifies to the fact that Bologna Process model higher education reform outside Europe may not only vary from country to country but also within the same country. Interpreting transcripts from such countries can be tricky and misleading. American colleges and universities attracted to graduate students from Europe and other countries implementing various forms of the reform must try to know the salient differences in models within Europe, betweenuniversities in the same country, and between the worldwide regional models.

Knowing the minute details on the extent of the Bologna impact on tertiary education programs in these regions of the world and more is the only way the United States higher educational leaders and institutions would ensure constructive and beneficial mutual exchanges in study abroad, joint and dual degree offerings, faculty and student mobility programs. Degree interpretations and transferability and soundness of admission decisions of students from these regions will depend entirely on the understanding admission officials in US colleges and universities have of the Bologna Process reform and the varying Bologna models used in institutions from these regions. Studies show that significant differences still exist in areas such as the credit counts and degree structures among countries that have adopted the BP model and among educational establishments within countries $[39,40]$.

Considering that theUnited State remains the world's biggest host of international students, many of whom come from countries implementing some version of the BP, it is important that US educational institutions know these differences. Not knowing can lead to misinterpretation of qualifications with all unintended consequences. 


\section{Costs Competitive Disadvantages for the U.S.}

The United States is likely to become further weakened in the competition for international students because the cost of education in the United States has surged more than 500 percent since 1985 [41]. Cost is having a direct effect upon access and affordability, which constitute the main reasons for the drop in the number of graduates from U.S. four-year degree programs. The U.S. is significantly losing ground as the global leader in producing college graduates-ranked first in 1990, the country currently ranks twelfth in graduation rates among 25-34-year-olds[41]. While America lags incollege graduation rates largely due to unaffordability, the situation of Germany, the largest European country, is the complete opposite.

Today, German higher education is publicly funded, and students pay no tuition fees, even as the country embarks upon a large-scale internationalization of education, aided not only by the absence of tuition fees but also by its reputation for higher education quality in the sciences $[25,41]$. European countries that do charge tuition still have a big competitive advantage over the United States in terms of college affordability because the rates of tuition are insignificant compared to what students in the United States pay, including those attending state colleges and universities. In France, one of the citadels of European higher education, students pay about 200 dollars in tuition in public universities. These access-related advantages for European higher education should be a source of grave concern for U.S. higher education, especially when examined within the context of the incrementally popular Bologna models of higher education.

Colleges and Universities in the United States must understand the Bologna credits system and its European credit transfer system (ECTS) in order to facilitate European degree interpretations and the admission of students from Europe and regions such as Australia, Latin America, and Africa where the Bologna model has gained ground.Even though the major outcomes of the Bologna Process reform have been the development of degree programs that are defined in terms of required credits and the introduction of a two-tiered (undergraduate/graduate) system, the new European bachelor's degree is still different in many aspects to its United States counterpart. In the April/March issue of WENR, Assefa and Sedgwick [42] raise the difficulty of United States graduate schools in evaluating potential European graduate students with the three-year Bologna bachelor's degree.

This is particularly difficult because a UnitedStates bachelor's degree typically requires the completion of 120 credits and spans four years. They compared a business BA program from the Kelly School of Business in Indiana and the laurea program in business administration from the Bacconi University in Italy and concluded that the Italian laurea is functionally equivalent to the United States bachelor's degree. These conclusions gave the impression that the degree interpretation process could be easy. However, this couldn't be farther way from the reality, considering that variations in quality and interpretation of the Bologna recommendations as well as the pace of implementation of the Bologna process still exist among EU countries [20].

Focusing particularly on legal education, Terry [37] further elaborates on the implications of the Bologna Process upon the United States legal education. The areas of concern for the United States legal education include admissions, recognition, accreditation, and quality assurance. Law schools must decide whether to provide full admission or provisional admission for students coming from Europe into their JD, LLM, or SJD programs. He explains that unjustified differences exist in the admission requirements, depending on institutional policy. He contends that in the face of such discrepancies it will be necessary for the United States to come up with a common higher education policy to handle interpretation issues resulting from the European Credit Transfer System (ECTS) used by the Bologna Process reform.

The probability of this happening is slim because collaboration between state jurisdictions is likely in America, but an overall agreement is not. In the U.S., the autonomy of each institution is valued to a highly significant extent. However, even though the federal government is beginning to push for even more authority there is hardly any agreement as to howmuch power the federal government should have in matters of education. Assefa \& Sedgwick[42] point to an interesting future while stating thatfailure to recognize the Bologna bachelor's degree solely because it is a three-year qualification would leave United States graduate schools no choice but to reject candidates who apply for admission using these degrees, even when their records demonstrate that they have completed more than enough subjects in their discipline, have achieved the same skills and level of knowledge as their U.S. counterparts, and would very likely succeed at the graduate level.

Such decisions would not only lack any academic merit, but they would also have profound and negative implications for international academic mobility. According to some critics, the United States higher education system is characterized byconsiderable program and certification requirement differences between its constituent states.These occasionally lead to unnecessary re-certifications of professionals who have alreadyundertaken the requisite training [43]. The logical explanation of this isthat United States higher education has not embraced more uniformity in important areas such asprofessional training. The United States stands to gain by observing the Bologna Process reform, which seeks to strengthen and harmonize professional training in order to facilitate student,faculty, and labor mobility within the EU.

The scale of European higher education outreach has grown tremendously since 1999.The Bologna Process objective of improving the attractiveness of European higher education isbeing achieved. The corollary of this is the influx of foreign students into Europe, encouraged bythe incentives in tuition and the easing of 
visa requirements. Helguero-Balcells [43] arguesthat the United States higher education will only remain viable in the long term if there is "alignment with the Bologna Agreement" (p. 1) and the strengthening of exchanges with nationaland international partners which would benefit all stakeholders. The problem with thisproposition is that alignment with Bologna might be more of a political than educationaldecision, involving the 50 states of the United States-hence intricate and controversial.

Rather,more cooperation with EU countries and other regions of the world, the extension of existing programs, and the creation of new ones would keep the United States more active and competitive in international higher education. Cooperation with EU countries and universities would naturally mean that the U.S. education stakeholders must be more accepting of degrees and graduates from the Bologna model higher educational institutions.No one knows yet what direction United StatesEuropean cooperation in higher education will take in the latter part of the 21st century. Notwithstanding this, the United States must come up with new frameworks and legislation that would facilitate the interpretation of European qualifications-including the mobility of students and the comparability of degrees between the United States and Europe and all the other Bologna Processrelated higher education systems [37].

Good knowledge and understanding of European curricula, structures, and degrees in the United States would equally facilitate the appreciation and interpretation of certificates from Bolognastyle systems, such as the emerging BMD (LMD) in Africa, Asia, and Asia-Pacific countries.Even though the United States must not adopt the Bologna style reform, it cannot ignore its influence either. With higher education institutions and programs that have gained international reputation, there is apparently no motivation for the United States colleges and universities to be interested in the Bologna models.

Apart from costs that put the United States tertiary education institutions at a competitive disadvantage, quality remains the forte of the U.S. models. In his criticism of the initial tepid United States response to the Bologna Process, Adelman [14] contended that "such purblind stances are unforgiveable in a world without borders" (p. 8). In other words, he was saying that a war against higher education internalization is a losing one.The U.S. has been the top exporter of higher education services worldwide for decades. The U.S. is eager to retain its leadership status in global higher education in the face of the increasing competition from Europe instigated by the Bologna Process harmonization and its adoption of extensive marketing strategies to attract foreign students.

This rivalry can only be beneficial to higher education in that colleges and universities will not only work hard to improve, they will also improve costs in order to attract students. The discrepancies in costs between United States and European tertiary education institutions are already beginning to give Europe a competitive advantage.The U.S. Government Accountability Office (2009) highlighted the decline the UnitedStates' share of international students worldwide from $26 \%$ to $20 \%$ between 2000 and 2008 even though it remained the leading destination for international students. In 2008 Institute of International Education (IIE) Open Doors Report asserted that the decline in the number of international students attending U.S. higher education institutions between 2003 and 2006 was the first drop in over 30 years. According to the IIE and U.S. Department of State Bureau of Education and Cultural Affairs (2017), the number of international students enrolled for the first time in dropped by about 10,000 students, representing a three-percent decrease from the previous year. The report underscored the important fact that the decline is the first in twelve years.

The competition from continental European countries and from other attractive Bologna models in Eastern Europe, Asia-Pacific, and Africa and Latin America makes it illogical for the United States to take for granted its leading position since prospective international students now have many attractive alternatives from which to choose. Urias and Yeakey [44] point out that other countries have used the opportunity created by the tightening of screening procedures andvisa issuance by the United States government to attract international students to their own educational, scientific, and technical institutions. The United States needs to strike a delicate balance between ensuring its security amidst terrorist threats and participating in the global community in a way which empowers Americans to compete in a global workforce, while also being open, accessible, and attractive to the world's best talent and future leaders [45].

\section{Summary}

An outcome of the Bologna Process has been a steady increase of English language programs in universities in continental Europe. This development, which added to the adoption of models that facilitate degree interpretations and transferability as well as student and faculty mobility, has undoubtedly improved the appeal of European degrees in and Europe and beyond. These BPinspired programs have continued to act as a magnet for many international students, who before 1999 were only attracted to the United States of America and the United Kingdom. A review of pre-BP and post-BP reform indicate that the ongoing progress in international interpretation and recognition of diplomas and degrees as well as global improvements in quality assurance mechanisms are not unrelated to the reform. Research into the impact of the Bologna Process on international higher education suggests that the reform has significantly improved the competitiveness of European higher education [46].

To explain the drop in the number of foreign students in American Universities in favor of European Universities at the beginning of the 21st century, Gillespie [47] and the U.S. Government Accountability Office (2009) pointed to the homeland security policies developed after the September 11, 2001 events as having undermined the openness of the American education 
system to foreign students. However, the drop in the enrollment of foreign students inU.S. colleges and universities post-September 11, 2001 could also be attributed, arguably, to the increasing attractiveness of European higher education following the 1999 Bologna reform.

An important point to note is that, overall, U.S. colleges and universities continue to win the completion for international students even when periodic drops in enrollments are identified-between 1999 and 2017 there was a steady increase $26.72 \%$ in enrollment (NCES,2017). The current significant dip in international students' enrollment is largely attributed to the tightening of visa policies by the Trump administration. Trines [26] attributed the decline in the number of students from the top 24 sending countries-by 1,900 (1.85\%) from November 2016 to Aprils 2017-to the "Trump effect." He argues that the dip, even though small, represents the largest downward fluctuation between fall and spring quarters since 2014, the first year SEVIS data was made available online.With trends indicating recent minor dips in international students' enrollments in the U.S. resulting from other factors, the big question is whether Europe, with its more attractive Bologna models, will take advantage of the situation[48].

The positive trends in the popularity of European higher education will likely continue if institutions such as the European Union and the European Commission, as well as individual countries such as France, the UK, and Germany, continue to promote higher education exchange and collaboration at institutional, governmental, and regional levels. American colleges, universities, and higher education stakeholders must up their game in order to continue having a competitive edge in the recruitment of international students. It is not clear yet whether the imminent departure of Britain from the EU and withdrawal from Bologna Accords will affect the BP implementation or whether such an effect or lack thereof will have any bearing on the competitiveness of the Bologna models of higher education[49-53].

\section{References}

1. Egron-Polak, E (2008) The Bologna Process: Reflections from the international HEI perspective. International Association of Universities (IAU), Paris, Europe.

2. Zgaga, $P(2006)$ 'External dimension' of the Bologna Process ( $1^{\text {st }}$ Report on the External Dimension of the Bologna Process). Report from Athens Seminar. The Working Group, Athens, Greece.

3. Prague Report (2009) The European Higher Education Area (EHEA) in a global context: Report on overall developments at the European, national and institutional levels. Prague, Czech Republic: Australian Federal Ministry of Science and Research, Australia.

4. Labi, A (2007) Europe challenges the US for foreign students. The Chronicle of Higher Education 54(5): A29.

5. Labi, A (2009) European colleges lead U.S. in international dual-degree programs, study finds. The Chronicle of Higher Education 55(22): A26.

6. Bond, S (2003) Untapped resources. Internationalization of the curriculum and classroom experience: A selected literature review (CBIE Research Millennium Series, 7, 15). Canada Bureau of International Education, Ottawa, Canada.
7. Ka-ho Mok, J, Lee, H (2001) Globalization and changing governance: Higher education reforms in Hong Kong, Taiwan, and Mainland China. Paper presented to the Australian Association for Research in Education 2001 Conference.

8. Altbach, PG (1991) Patterns in higher education development: Toward the year 2000. Review of Higher Education 14(3): 293-315.

9. Altbach, PG (2004) Globalization and the university: Myths and realities in an unequal world. Tertiary Education and Management 10(1): 3-25.

10. Altbach, PG, Knight, J (2007) The internationalization of higher education: Motivations and realities. Journal of Studies in International Education 11(3-4): 290-305.

11. Teferra, D, Altbach, PG (2004) African higher education: Challenges for the 21st century. Higher Education 47(1): 21-50.

12. Fielden, J (2001) Markets for "borderless education." Minerva 39(1): 49-62.

13. Chang, FFC (2004) Instructors' perceptions of higher technological and vocational education reform in Taiwan, the Republic of China (Doctoral dissertation). Available from ProQuest Dissertations and Theses database. (UMI No. 3169553)

14. Adelman, C (2009) The Bologna Process for U.S. eyes: Re-learning higher education in the age of convergence. DC: Institute for Higher Education Policy, Washington, US.

15. The Times of Higher Education Supplement (2003) Education minister wants France to set European model. World Education News \& Reviews 16(6).

16. Clark, N (2007) The impact of the Bologna Process beyond Europe, part II. World Education News \& Reviews 20(9).

17. Clark, N (2014) Towards a European Higher Education Area: 15 Years of Bologna. World Education News and Reviews.

18. European Commission/EACEA/Eurydice (2012) The European Higher Education Area in 2015: Bologna process implementation report. Publications Office of the European Union, Luxembourg, Europe.

19. European Commission (2013) Communication from the Commission to the European Parliament, the Council, the European Economic and Social Committee and the Committee of the Regions: European higher education in the world. Europe.

20. European Commission/EACEA/Eurydice (2015) The European Higher Education Area in 2015: Bologna Process Implementation Report. Publications Office of the European Union, Luxembourg, Europe.

21. Bologna Declaration (1999) Joint declaration of the European Ministers of Education. Italy: The European Higher Education Area, Bologna, Italy.

22. Douglass, JA, Edelstein, R (2009) The global competition for talent: The rapidly changing market for international students and the need for a strategic approach in the U.S. Center for Studies in Higher Education 8(9): 1-14.

23. McCormack, E (2005) Enrollment of foreign students falls for a second year. Chronicles of Higher Education: International 52(13): A1.

24. Gardner, D, Witherell, S (2003) Open doors 2003: International students in the U.S. A Report of the Institute of International EducationIIE.

25. Trines, S (2016) Education in Germany. World Education News and Reviews.

26. Trines, S (2017) SEVIS data points to declining enrollments from key countries. World Education News and Reviews.

27. Courts, $\mathrm{AD}$ (2004) Internationalizing an institution: An emerging model of effective leadership, infrastructure, and cultural factors 
(Doctoral dissertation). Available from ProQuest Dissertations and Theses database. (UMI No. 3162073)

28. Auden, WH (1937) Journey to Iceland: Letters from Iceland. England: Faber \& Faber, London, UK.

29. Burn, B (1980) Explaining the international dimension of higher education. Jossey-Bass, San Francisco, US.

30. Ross, A (2008) The offshore models for universities. Liberal Educator 9(4): 34-39.

31. Brennan, J, Locke, W, Naidoo (2007) United Kingdom: An increasingly differentiated profession. In W. Locke \& U. Teichler (Eds.), The changing conditions for academic work and careers in select countries (pp. 262 276). International Centre for Higher Education Research, Kassel, Germany.

32. WTO Council for Trade in Services (1998) Education services Background note by the Secretariat.

33. Reinalda, B, Kulesza, E (2006) Bologna Process: Harmonizing Europe's higher education (2nd rev. ed.). Barbara Budrich, Farmington Hills, Michigan.

34. Wilen-Daugenti, T, McKee, AGR (2008) 21st century trends for higher education: Top trends, 2008-2009. Cisco Internet Business Solutions Group, San Jose, CA, US.

35. Forest, J (2004) Globalization and public policy trends in higher education: A comparative analysis. Paper presented at the annua meeting of the American Political Science Association, Chicago, Illinois.

36. Reimers, F (2009) 'Global Competency is imperative for global success. The Chronicle of Higher Education 55(21): A29.

37. Terry, LS (2007) The Bologna Process and its implications for U.S. legal education. Journal of Legal Education 57(2): 237-252.

38. Reichert, S, Tauch, C (2003) Trends 2003. Progress towards the European higher education area. Bologna four years after: Steps toward sustainable reform of higher education in Europe. Geneva, Switzerland/Brussels, European University Association, Belgium, Europe.

39. Eta, EA (2018) Educational policy borrowing: Adoption and adaptation of bologna process ideas in the Cameroonian higher education system (Doctoral Dissertation). University of Turku, Turku, Finland.

40. Eta, EB, Vubo, EY (2016) Global references, local translation: adaptation of the Bologna Process degree structure and credit system at universities in Cameroon. Globalisation, Societies and Education 14(4): 492-512.

41. Value Colleges (2018) College access and affordability: USA vs. the world.

42. Assefa, M, Sedgwick, R (2004) Evaluating the Bologna degree in the U.S. World Education News \& Reviews. 17(92).

43. Helguero-Balcells, G (2008) The Bologna declaration agreement impact on U.S. higher education: Recommendations for integration. The International Journal of Learning 16(10): 241-252.

44. Urias, D, Yeakey, CC (2009) Analysis of the U.S. student visa system: Misperceptions, barriers, and consequences. Journal of International Education 13(1): 72-109.

45. Johnson, VC (2009) A visa and immigration policy for the braincirculation era: Adjusting to what happened in the world while we were making other plans. NAFSA e-Publications, US.

46. Mngo, Z (2011) Instructors' perceptions of the Bologna model of higher education reform in Cameroon (Doctoral dissertation). Available from ProQuest Dissertations and Theses database.

47. Gillespie, SH (2002) The practice of international education in the context of globalization: a critique. Journal of Studies in International Education 6(3): 262-267.

48. Institute of International Education (IIE) and the U.S. Department of State Bureau of Educational and Cultural Affairs (2017). Report on International Educational Exchange. Open Doors Report.

49. Blight, D, West, L (2000) Demand for transnational higher education in the Asia Pacific. Australia: Leo West Consulting, Melbourne, Australia.

50. Gorga, A (2008) Where are we with the harmonization of European higher education? The case of Central and East European countries. European Education, 39(4): 58-68.

51. Grill, KM, Carver, L (2008) Organizational change as sensemaking, not resistance, in NBC's The Office. Paper presented at the annual meeting of the NCA 94th Annual Convention, TBA, San Diego, CA, US.

52. Grummon, PTH (2009) Trends in higher education. Society for College and University Planning 6(1): 1-10.

53. Institute of International Education (IIE) and the U.S (2008) Department of State Bureau of Educational and Cultural Affairs. Report on International Educational Exchange. Open Doors Report.

\begin{tabular}{l} 
Your next submission with Juniper Publishers \\
will reach you the below assets \\
- Quality Editorial service \\
- Swift Peer Review \\
- Reprints availability \\
- E-prints Service \\
- Manuscript Podcast for convenient understanding \\
- Global attainment for your research \\
- Manuscript accessibility in different formats \\
( Pdf, E-pub, Full Text, Audio) \\
- Unceasing customer service \\
Track the below URL for one-step submission \\
https://juniperpublishers.com/online-submission.php \\
\hline
\end{tabular}

